

Review Article

https://doi.org/10.20546/ijcmas.2017.604.113

\title{
Use of Tree Species in Controlling Environmental Pollution-A Review
}

\author{
R. Nithya*, S.Poonguzhali and S.Kanagarasu \\ Department of Horticulture, Thanthai Roever Institute of Agriculture and Rural \\ Development, Perambalur- 621 115, India \\ *Corresponding author
}

\begin{abstract}
A B S T R A C T
Air pollution is a heterogeneous, complex mixture of gases, liquids, and particulate matter. Air pollution has become increasingly visible in cities and towns across world. Many

\begin{tabular}{|l|}
\hline Ke y w o r d s \\
Environmental \\
Pollution, \\
Air pollution. \\
\hline Article Info \\
\hline $\begin{array}{l}\text { Accepted: } \\
\text { 06 March } 2017 \\
\text { Available Online: } \\
\text { 10 April } 2017\end{array}$ \\
\hline
\end{tabular}
factors contribute to air pollution including industry, lack of vehicular emission controls, dirt roads, poor fuel quality, open burning agricultural dust and pesticides and an expanding maquiladora industry. Our plan will lead to reductions in air pollutant emissions that cause smog and acid rain by up to $55 \%$ as early as 2018. To get there, our plan will set national caps for industrial emissions of four air pollutants commonly associated with smog and acid rain, namely nitrogen oxides, sulphur oxides, volatile organic compounds, and particulate matter. Caps will also be set for other air pollutants such as mercury from electricity produced by combustion, and benzene emissions from the natural gas, and iron and steel sectors. Plants plays significant role in mitigation the air pollution and maintains ecological balance. Plants acts as the scavengers for air pollution as they are the initial acceptors. Various pollutants can be absorbed accumulated by the plants results in reducing the pollutant levels in the environment. The identification of the tolerant plant species suggests suitable plant species to green-belt development and social-forestry programs.
\end{abstract}

\section{Introduction}

Air is important for life on the earth. Rapid increasing of population and development leads to the deterioration of quality of air. From one year to next year, the concentration of pollutions are increasing even there is some differences in between the nations. Every year, more than 308 crore tons of $\mathrm{CO}_{2}$ and other pollutants are releasing into the earth's atmosphere. Plants are very important to maintain ecological balance but they can severely get effect directly or indirectly by air pollution (Steubing et al., 1989; Agbaire, 2009). Plants acts as the scavengers for air pollution as they are the initial acceptors (Joshi and Swami, 2009). Various pollutants can be absorbed accumulated by the plants results in reducing the pollutant levels in the environment (Liu and Ding, 2008). Now a day, urban vegetation became very important because it affects the local and regional air quality (Jissy Jyothi and Jaya, 2010). The impact of air pollution on plants can be evaluated by manipulating the tolerance levels of plant species.

Many factors contribute to air contamination on the border including industry, lack of vehicular emission controls, dirt roads, poor fuel quality, open burning (Crespin, 1994), agricultural dust and pesticides, and an 
expanding maquiladora industry (English, 1998). Especially vulnerable to these environmental problems is the large lowincome population that lives along the border. Like many low-income minority groups, low income border residents are more likely to be exposed to outdoor air pollutants and live in substandard housing with inadequate air circulation and filtration (Alexander et al., 2000).

\section{Air Pollution}

The ambient air quality at various locations, a monitoring network has been established comprising of 295 stations covering 98 cities/towns in 29 States and three Union Territories under the Air (Prevention and Control of Pollution) Act, 1981, as amended in 1988. Under this programme, four criteria air pollutants viz. Sulphur dioxide $\left(\mathrm{SO}_{2}\right)$, oxides of nitrogen (NOx), Suspended Particulate Matter (SPM) and Desirable Suspended Particulate Matter (RSPM) are regularly monitored at all the locations. Besides this, additional parameters such as desirable lead and other toxic trace matters and polycyclic aromatic hydrocarbons are also being monitored in 10 metro cities of the country. The ambient air quality is monitored by Central Pollution Control Board (CPCB) in coordination with the State Pollution Control Boards, Pollution Control Committees and some of the universities and research institutes.

\section{Effect of Vegetation on Air Quality}

Removal of dust particles by vegetation through interception from the atmosphere enhances air quality in urban areas (Beckett et al., 1998, 2000; Freer-Smith et al., 2005), near roadways (Smith, 1971; Freer-Smith et al., 1997). Properties of both particles and the vegetation are important in deciding their interactions, and consequently the effectiveness of particle removal from atmosphere. Leaves, susceptible and highly exposed parts of a plant, may act as persistent absorbers in a polluted environment (Maiti, 1993). Small vegetation elements are more effective in removing small particles from an air stream than are large elements. They act as pollution receptors and decrease dust concentration of the air. The capability of leaves as dust receptors depends upon their surface geometry, phyllotaxy, epidermal and cuticular features, leaf pubescence, and height and canopy of trees (Fowler et al., 1989; Nowak, 1994; Beckett et al., 2000; Raupach et al., 2001). Prajapati and Tripathi (2008a-d) have shown that pollution tolerant tree species can be used for green belt development.

\section{Effects of Particulate Matter on Vegetation}

Exposure to a given mass concentration of airborne PM may lead to widely differing phototoxic responses, depending on the particular mixture of deposited particles. Particulate deposition and effects on vegetation unavoidably include (1) Nitrate and sulfate and their associations in the form of acidic and acidifying deposition and (2) Trace elements and heavy metals, including lead.

While size is related to mode and magnitude of deposition, and may be a useful substitute for chemical composition (Whitby, 1978). Mineral dusts in general are less soluble and less reactive than the anthropogenic acidforming sulfate and nitrate particles (Fowler et al., 1989; Grantz et al., 2003). Dusts with $\mathrm{pH}$ values of $\geq 9$, may cause direct injury to leaf tissues on which they are deposited (Vardak et al., 1995) or indirectly through alteration of soil $\mathrm{pH}$ (Hope et al., 1991; Auerbach et al., 1997) and dusts that carry toxic soluble salts will also have adverse effects on plants (Prajapati and Tripathi, 2008a-d). 


\section{Selection of planting material}

Selecting trees for urban planting in order to have the highest establishment rate and growth performance and to lowest maintenance costs (From Harris et al., 2004). Aesthetics certainly have high relevance in plant selection, but the value of a plant should go far beyond aesthetic appeal. Function guides the selection of a species and we all know that the choice of high quality planting material is the first link to establish a sustainable urban landscape and its importance is obvious. Planting projects can fail because of poor quality plants and when the wrong species or variety is planted.

The first step is to analyze the sensitivity of the different species to the urban conditions and to global change (Ferrini et al., 2008). The assessment should identify whether these factors could cause significant negative impacts on tree growth and physiology. If a species appears to be insensitive to climate change and to the typical urban stress, city planners and arborists should move on the next step-that is site assessment and modification (if needed) and planting. If a species appears to be sensitive to climate change, there will be a need to select potential alternative species. As reported by Schutzki and Tripp (2008), function, aesthetics, site adaptability and management form the foundation of Right Plant/Right Place/Right management adage and have been used for years to identify appropriate plants for a given landscape.

Recurrent human health disturbances related with seasonal shedding of pollen are common results of improper selection of tree species for urban planting. As underlined by Sogni (2000), pollen responsible for the principal allergic reactions comes mostly from anemophilous species which, in general, produce large quantities of pollen and depend on poorly selective diffusion agents such as wind. Typically, grains of such pollen are very light and small with a smooth, dry surface. Their diameters usually range from 20-30 $\mu \mathrm{m}$ with maximums of $150 \mu \mathrm{m}$ in some Coniferous species. In contrast, Entomophilous species produce pollen which is frequently bigger and heavier. As poorly dispersed through the air, it is rarely present in the atmosphere at concentrations sufficient to trigger an allergic reaction. However, there are exceptions such as Tilia, an Entomophilous genus that can also cause an allergic response. In cases where air-borne spread of pollen is limited, violent allergic reactions are recorded mainly after direct contacts with the pollen producing plant.

\section{Tree stability assessment}

This subject was already reviewed by Ferrini et al., (2008) who underlined its importance when selecting trees in a global change scenario. The need to rethink tree stability assessment to meet changing objectives lies at the heart of the research into sustainable urban forest management. We know that trees in the urban environment often have to face very harsh conditions. They can easily acquire mechanical defects, which may cause hazard in areas where people and property are present. According to the existing definition: "hazard is a disposition of a thing, condition, or situation to produce injury" (Health and Safety Executive, 1995), in a more specific way a tree is considered to be hazardous, if it is structurally unsound and there is a possible target, like vehicles or people. An unsound tree in an area with no target is not hazardous (Dujesiefken et al.., 2005). Although all trees have a potential to fail and become hazardous in particular conditions, senescent trees are most prone to acquire these characteristics. In such trees all functions, including photosynthesis, production of roots, stem growth and branching, resistance to 
pathogens, and others are gradually reduced or disorganized.

\section{Tree selection and maintenance in the} urban environment

Tree planting in the urban environment is particularly effective because: 1) They have a direct effect of $\mathrm{CO}_{2}$ by fixing it through photosynthesis; 2) Through shading and wind-screening they can effectively reduce the need of fossil fuels for house-warming and summer cooling. The net save in carbon emissions that can be achieved by urban planting can be up to $18 \mathrm{~kg} \mathrm{CO}_{2} /$ year per tree Rosenfeld et al.., 1998), and this benefit corresponds to that provided by 3 to 5 forest trees of similar size and health (Akbari, 2002).

Most of the existing models for estimating $\mathrm{CO}_{2}$ sequestration by trees are generally based on above-ground biomass production as stem diameter, plant height, crown size and age (Nowak, 1994; Nowak e Crane, 2002; Banks et al.., 1999; Brack et al.., 1999; Brack, 2002). Errors of such estimates can be substantial: Nowak (2002) calculated an average yearly $\mathrm{CO}_{2}$ uptake of $30 \mathrm{~kg}$ by a healthy 23-30 cm caliper tree. The uptake rate of a similar tree was quantified in 4-10 $\mathrm{kg} /$ year by Akbari (2002). Moreover many models don't take account of carbon store in roots, which may be up to $23 \%$ of total carbon storage, depending also on the growing condition (i.e. a tree grown in full sun or in water-limiting conditions will allocate more carbon to below-ground parts than an identical tree grown in optimal conditions).

\section{Ambient air quality}

Under the National Ambient Air Quality Monitoring (NAAQM) network, three criteria air pollutants, namely, $\mathrm{SPM}, \mathrm{SO}_{2}$, and $\mathrm{NO}_{2}$ have been identified for regular monitoring at all the 290 stations spread across the country. CPCB (2000c) analyses the status and trends of air quality at various cities in India for the period 1990-98. Annual averages of SPM, $\mathrm{SO}_{2}$, and $\mathrm{NO}_{2}$ in 16 cities in the country between 1990 and 1998, the most prevalent form of air pollution appears to be SPM although there are many stations at which $\mathrm{SO}_{2}$ and $\mathrm{NO}_{2}$ levels exceed permissible limits.

\section{SPM}

Suspended particulate matter is one of the most critical air pollutants in most of the urban areas in the country and permissible standards are frequently violated several monitored locations. Its levels have been consistently high in various cities over the past several years. The annual average minimum and maximum SPM concentration in residential areas of various cities ranged from $60 \mu \mathrm{g} / \mathrm{m}^{3}$ (at Bangalore during 1991) to $521 \mu \mathrm{g} / \mathrm{m}^{3}$ (at Patna during 1995), while in industrial areas the annual average ranged between $53 \mu \mathrm{g} / \mathrm{m}^{3}$ (Chennai during, 1992) and $640 \mu \mathrm{g} / \mathrm{m} 3$ (Calcutta during, 1993). The mean of average values of SPM for nine years (1990 to 1998) ranged between $99 \mu \mathrm{g} / \mathrm{m}^{3}$ and $390 \mu \mathrm{g} / \mathrm{m}^{3}$ in residential areas and between $123 \mu \mathrm{g} / \mathrm{m}^{3}$ and $457 \mu \mathrm{g} / \mathrm{m} 3$ in industrial areas indicating that the annual average limit of suspended particulate matter for residential areas $\left(140 \mu \mathrm{g} / \mathrm{m}^{3}\right)$ and for industrial areas $\left(360 \mu \mathrm{g} / \mathrm{m}^{3}\right)$ had been frequently violated in most cities. The maximum suspended particulate matter (SPM) values were observed in Kanpur, Calcutta, and Delhi, while low values have been recorded in the south Indian cities of Chennai, Bangalore, and Hyderabad.

\section{Status of other air pollutants}

The salient results of additional parameters at some stations in the metropolitan cities of Delhi, Calcutta, Mumbai, and Chennai for the 
years 1996-97 are as follows (CPCB 1998): The annual mean concentration of desirable particulate matter (RPM) is much higher than the prescribed limits of $120 \mu \mathrm{g} / \mathrm{m}^{3}$ (industrial) and $60 \mu \mathrm{g} / \mathrm{m}^{3}$ (residential and other uses) in Delhi and Calcutta. However, RPM in Mumbai and Chennai is not very high but is greater than prescribed ambient air quality standards though particulate lead in the ambient air of Calcutta and Delhi is higher as compared to the other two cities (Chennai and Mumbai), it is well within the prescribed limits for the different area classes. The concentration of polycyclic aromatic hydrocarbons (PAHs) is showing an upward trend. However, at present permissible limits for PAHs have not been notified, it may be noted that lead free gasoline has been introduced throughout the country w.e.f. February 1, 2000, and in all metropolitan cities since 1995. This has resulted in a downward trend in the lead concentrations in the ambient air (CPCB 2000c).

\section{Air quality at traffic intersections}

Air quality monitoring conducted at different traffic intersections in Delhi (MoEF, 2000a) revealed the following:

Respirable particulate matter was excessively high at all the monitoring locations.

Sulphur dioxide was recorded within limits at all the locations.

Nitrogen dioxide was recorded well within the limits except a few locations.

\section{Air pollution and health impacts}

In India, millions of people breathe air with high concentrations of dreaded pollutants. The air is highly polluted in terms of suspended particulate matter in most cities. This has led to a greater incidence of associated health effects on the population manifested in the form of sub-clinical effects, impaired pulmonary functions, and use of medication, reduced physical performance, frequent medical consultations and hospital admissions with complicated morbidity and even death in the exposed population. As per a World Bank (1993) study, respiratory infections contribute to $10.9 \%$ of the total burden of diseases, which may be both due to presence of communicable diseases as well as high air pollution levels, while cerebra vascular disease $(2.1 \%)$ ischemic heart disease $(2.8 \%)$ and pulmonary obstructions $(0.6 \%)$ are much lower. The prevalence of cancer is about $4.1 \%$ amongst all the diseases indicating that the effects of air pollution are visualized on the urban population (CPCB, 2000c). A WHO /UNEP study compared standardized prevalence of respiratory diseases in different areas of Mumbai, classified according to ambient average concentrations of sulphur dioxide. The study revealed a relatively higher prevalence of most respiratory diseases in polluted urban areas than in the rural control area (WHO/UNEP, 1992, cited in Repetto, 1994). In India, in a study of 2031 children and adults in five mega cities, of the 1852 children tested, 51.4\% had blood lead levels above $10 \mu \mathrm{g} / \mathrm{dl}$. The percentage of children having $10 \mu \mathrm{g} / \mathrm{dl}$ or higher blood lead levels ranged from $39.9 \%$ in Bangalore to $61.8 \%$ in Mumbai.

In conclusion, tree impacts on important atmospheric trace chemicals such as carbon dioxide and U.S. Environmental Protection Agency criteria air pollutants (ozone, particulate matter, sulfur dioxide, nitrogen dioxide, carbon monoxide, and lead) will have greater significant impacts on human health and environmental quality. The exposure to dust pollution stress provoked important reductions in photosynthesis in most studied plants except Polyalthia 
longifolia. Moreover, accumulation of dust particulates on studied plant leaves could be a major problem in their production. Plants plays significant role in mitigation the air pollution and maintains ecological balance. The determination of Air Pollution Tolerance Index (APTI) to the plant species in urban area is important to implement pollution control methods. The identification of the tolerant plant species suggests suitable plant species to green-belt development and socialforestry programs.

\section{References}

Agbaire. 2009. Air pollution tolerance indices (APTI) of some plants around ErhoikeKokori oil exploration site of Delta State, Nigeria. Int. J. Physical Sci., Vol. 4(6): 366-368.

Akbari, H. 2002. Shade trees reduce building energy use and $\mathrm{CO} 2$ emissions from power plants. Environ. Pollu., 116: S119-S126.

Beckett, KP., P.H. Freer-Smith. and G. Taylor. 1998. Urban woodlands: their role in reducing the effects of particulate pollution. Environ. Pollu., 99: 347-360.

CPCB. 2000c. Air Quality status and trends in India, National Ambient Air Quality Monitoring Series: NAAQMS/14/19992000. Delhi: Central Pollution Control Board.

CPCB. 2000c. Air Quality status and trends in India, National Ambient Air Quality Monitoring Series: NAAQMS/14/19992000. Delhi: Central Pollution Control Board.

Crespin, F. 1994. Overview of border health issues. Border Health J., 10(2): 25-29.

Dahl, R. 2004. NAFTA Worries in Juárez. Environ. Health Perspectives, 112(17): A985-A985.

Dujesiefken, B., Drenou, C., Oven, P., Stobbe, H. 2005. Arboricultural practices. In: Urban Forests and Trees.
(Kjonijnendijk, C., Nilsson, and Randrup, T.B. eds), Springer, 419-441.

Ferrini, F., A. Fini, P. L. Marasco, L. Pennati and L. Sani. 2008. How to select trees that will thrive in urban environments, given differences in urban sites, species attributes, management requirements and global change. ISAAC 9th-14th May 2008, Brisbane- Australia.

Fowler, D., Cape, J.N., Unsworth, M.H. 1989. Deposition of atmospheric pollutants on forests. Philosophical Transactions of the Royal Society of London, 324: 247265.

Harris, R.W, J.R. Clark, N.P., Matheny. 2004 Arboriculture, 4th Ed. Prentice Hall Inc., New Jersey 07658.

Jissy Jyothi and D.S. Jaya. 2010. Evaluation of Air pollution tolerance index of selected plant species along roadsides in Tiruvananthapuram, Kerala. J. Environ. Biol., Vol 1: 379-386.

Joshi and Swami. 2009. Air pollution induced changes in the photosynthetic pigments of selected plant species. J. Environ. Boil., 30: 295- 298.

Liu and Ding. 2008. Variation in air pollution tolerance index of plants near a steel factory: Implication for landscape-plant species selection for industrial areas. Wseas Trans. Environ. Dev., 4: 24-32.

Loganathan, M., Muhammad Ilyas, M.H. 2012. Impact of cement dust pollution on morphology and histology in some medicinally significant plants. Int. J. Comprehensive Pharmacy, 11(6).

Maiti, S.K. 1993. Indian J. Environ. Protection, 13: 276-280.

MoEF. 2000a. Annual report (1999-2000), http://envfor.nic.in/report, June 2000. New Delhi: Ministry of Environment and Forests.

Nowak, D.J. 1994. Air pollution removal by Chicago's urban forest. In: Chicago's Urban Forest Ecosystem: Results of the Chicago Urban Forest Climate Project 
(McPherson EG, Nowak DJ, Rowntree RA, eds). 63-81, USDA Forest Service General Technical Report NE-186, USA.

Nowak, D.J., D.E. Crane. 2002. Carbon storage and sequestration by urban trees in the USA. Environ. Pollu., 116: 381389.

Prajapati, S.K., Tripathi, B.D. 2008a. Anticipated performance index of some tree species considered for green belt development in and around an urban area: a case study of Varanasi City, India. J. Environ. Manage., 88(4): 1343-1349.

Prajapati, S.K., Tripathi, B.D. 2008 b. Biomonitoring seasonal variation of urban air Polycyclic Aromatic Hydrocarbons (PAHs) using Ficus benghalensis leaves. Environ. Pollu., 151: 543-548.

Prajapati, S.K., Tripathi, B.D. 2008c. Management of hazardous road derived respirable particulates using magnetic properties of tree leaves. Environ. Monitoring and Assessment, 139(1-3): 351-354.

Prajapati, S.K., Tripathi, B.D. 2008d. Seasonal variation of leaf dust accumulation and pigment content in plant species exposed to urban particulates pollution. J. Environ. Quality, 37: 865-870.

Raupach, M.R., Woods, N., Dorr, G., et al. 2001. The entrapment of particles by windbreaks. Atmospheric Environ., 35: 3373-3383.

Rosenfeld, A.H., J.J. Romm, H. Akbari, M. Pomerantz. 1998. Cool communities: strategies for heat island mitigation and smog reduction. Energy and Building, 28: 51-62.

Schutzki, R.E. and E.H. Tripp. 2008. Sustainable plant selection. The Michigan Landscape, 55-61.

Smith, W.H. 1971. Lead contamination of roadside white pine. Forest Sci., 17: 195-198.

Sogni, S. 2000. Arredo urbano ed allergie: le barriere fisiologiche al fruimento del verde pubblico. Acer, 2: 42-47.

Vice-President, International Society of Environmental Botanists, National Botanical Research Institute, Lucknow226001, India.

WHO/UNEP. 1992. Urban air pollution in megacities of the World. Oxford: Basil Blackwell, World Health Organisation/United Nations Environment Programme.

\section{How to cite this article:}

Nithya, R., S.Poonguzhali and Kanagarasu, S. 2017. Use of Tree Species in Controlling Environmental Pollution-A Review. Int.J.Curr.Microbiol.App.Sci. 6(4): 893-899. doi: https://doi.org/10.20546/ijcmas.2017.604.113 